UDC 004.9

\title{
SOFTWARE DETERMINATION OF THE OPTIMAL ROUTE BY GEOINFORMATION TECHNOLOGIES
}

Tvoroshenko I. S. - PhD, Associate Professor of the Department of Informatics, Kharkiv National University of Radio Electronics, Kharkiv, Ukraine.

Kramarenko O. O. - Master of Science, Land Surveyor Engineer, Geodetic and Surveying Center Limited Liability Company, Kharkiv, Ukraine.

\begin{abstract}
Context. The urgency of this work is to develop software for a multifunctional geoinformation guide supporting the state fire and rescue part by means of modern geoinformation technologies. The object of research is the infrastructure of the city of Kharkiv.

Objective. The aim of the study is to develop software for a multifunctional geoinformation guide for the automatic determination of the optimal transport route using modern geoinformation technologies to improve the fire-fighting efficiency in the city of Kharkiv.

Method. During the research, the general scientific methods were used: cartographic, system analysis and synthesis for definition and generalization of theoretical and methodological foundations of state building norms, modeling, higher mathematics, combinatory, as well as special methods of mathematical and geoinformation analysis. ArcGIS software platform for creating, managing, integrating, analyzing and distributing spatial data is used in the work. Methods used: programming in VBA and Python, geodesy, topography, geoinformatics, definition of computational time.

Results. The results obtained in the course of this research, namely: methodological, algorithmic and software of the multifunctional geographic information directory, are of practical significance, are real and are used by the Kotelevsky district sector of the Main Department of the State Service of Ukraine for Emergencies in the Poltava region, and may also be applied by the Main Directorate of the State Service of Ukraine for Emergencies in the Kharkiv region for the automatic determination of the optimal route in the operational arrival of the fire brigade with the help of geoinformation technologies, tools of mathematical and geoinformation analysis.

Conclusions. The spatial model of the city of Kharkiv has been further developed due to the use of geoinformation and mathematical analysis methods during software development, which allowed taking into account a set of important criteria. The spatial model of geoinformation support of state fire and rescue units of Kharkiv city has been improved due to the consideration and application of the road distribution criteria according to the categories, which made it possible to develop an effective software platform for rapid response. Prospects for further research include the development of an application for Android and IOS platforms with the possibility of compact use of the geographic information directory, as well as the inclusion of an interactive ArcGIS Online map, which reflects the real state of traffic load and the possibility of using relevant data when designing the recommended route.
\end{abstract}

KEYWORDS: graph theory, spatial data analysis, optimal transport route, geographic information system, buffer zone, computational time, modern geoinformation technologies, algorithm, city infrastructure.

\section{ABBREVIATIONS}

ESRI is an Environmental Systems Research Institute; FH is a fire hydrant;

GIS is a geographic information system designed for collecting, storing, processing, accessing, displaying and distributing spatial-temporal data, the basis of integration of which is geographic information;

IDLE is a Python software environment;

SBN is a State Building Norm;

SES is a State Emergency Service;

SFRU is a State Fire and Rescue Unit;

VBA is a Visual Basic for Application;

VFG is a Voluntary Fire Guard.

\section{NOMENCLATURE}

$\Delta x$ and $\Delta y$ is a difference between the coordinates $X_{2}$ and $X_{1}, Y_{2}$ and $Y_{1}$ respectively;

$b$ is a buffer width (buffer distance);

$|E|$ is a number of edges (positive);

$|V|$ is a number of vertices (positive);

$X_{1}, Y_{1}$ is an initial vertex of polylines;

$X_{2}, Y_{2}$ is a finite vertex of polylines;

$\left(x_{1}, y_{1}\right)$ and $\left(x_{2}, y_{2}\right)$ is a coordinates of endpoints for parallel buffer lines of each segment of a line on both sides of a segment on a perpendicular of length $b$.

\section{INTRODUCTION}

GIS is a new time and space orientation system, it incorporates modern information processing techniques and, at the same time, is accessible to most people. It should be noted that geographic information is the key to improving the decision-making process in a wide range of tasks, and its application allows providing at the new level of information base almost all services and on this basis providing the opportunity to solve technical, economic and other tasks [1].

One of the executive bodies, which most need modernization and automation of the work process, is the SES of Ukraine. During the study, a detailed analysis of this issue was conducted in the Kharkiv region. It is established that in the territory of the chosen area, by the year 2018 , there are 3580 potentially dangerous objects, of which 388 increased danger, 67 chemical-dangerous, 4 arsenals of ammunition storage and composition of rocket fuel components, which still contain explosive fireextinguishing elements of spent rocket fuel. Consequently, due to the presence on the territory of the investigated area of a significant number of technogenically hazardous objects, it is necessary to provide a modern 
level of technical equipment of the SES of the Kharkiv Region $[2,3]$.

Over the past three years, there has been a tendency to increase the number of fires in the city of Kharkiv.

However, the 2018 statistical indicator shows positive changes compared to 2015 [4]. Thus, the problem remains critical and needs urgent solution. It should be noted that with the increase in the number of fires the requirements for rapid response and the arrival of a fire truck to the place of origin of the fire are increasing. That is, one of the urgent problems is the optimization of transport routes.

For today, the modern tool for solving the abovementioned tasks is specialized software geoinformation support. Thus, the main prospect of this work was the decision of the transport issue on the organization of the operational arrival of a fire vehicle to the place of origin of the hearth. Therefore, the necessary information for the study of this issue is the state of road coverage of the territory of the city of Kharkiv. As well as establishing the relationship between the category of roads and the time of arrival of the car, for example, the implementation of the geographic information directory for the support of the SFRU on the territory of the city.

Consequently, the relevance of this work is to develop software for a multifunctional geographic information directory for support of the SFRU on the territory of the city of Kharkiv by determining the route of the operative arrival of the fire brigade by the controller of the SFRU by means of modern geoinformation technologies in order to increase the effectiveness of firefighting.

The object of study is the infrastructure of the city of Kharkiv. The spatial model of the city of Kharkiv is foreseen with geoinformation and mathematical analysis methods, which will increase the fire protection in the city, taking into account a set of certain criteria.

The subject of study is an instrument of geoinformation and mathematical analysis.

The purpose of the work is to develop software for a multifunctional geoinformation guide for the automatic determination of the optimal transport route using modern geoinformation technologies to improve the firefighting efficiency in the city of Kharkiv.

\section{PROBLEM STATEMENT}

This work is carried out in the context of improving the issues of operational fire protection in the city of Kharkiv, taking into account the need to manage in time a large database of spatial data by means of GIS [5].

It should be noted that all in the city there are 19 SFRU and 3 additional subdivisions of local fire brigade. The area of the city of Kharkiv is about $350 \mathrm{~km}^{2}$, which is large enough for such a number of SFRU. Each fire unit must take into account the distributed service radius and respond instantly to calls using GIS precisely when determining the optimal traffic route, taking into account stops $(\mathrm{FH})$, as well as providing alternative routes for the arrival of a fire truck in the event of road repairs, accidents or congestion.

(C) Tvoroshenko I. S., Kramarenko O. O., 2019

DOI 10.15588/1607-3274-2019-3-15
The source data are:

- a map of the city of Kharkiv (cloud infrastructure of ArcGIS Online);

- personally-vectored micro districts with houses, SFRU and FH, central axes of the city roads;

- classification of road cover according to SBN 360-

$92 * *$ «Urban planning. Planning and development of urban and rural settlements»;

- personally victories classification of the transport network of the city roads;

- classification of fire trucks by characteristics: tonnage and volume of tanks.

In the course of the work, the assumption was made that the categories of roads $\mathrm{I}-\mathrm{a}$ and $\mathrm{I}-\mathrm{b}$ do not have a significant difference from the qualitative indicators, therefore they were grouped into the general category I. In addition, it was assumed that all SFRU are equipped with medium-volume fire trucks, set the maximum possible speed on different categories of roads.

According to expert data, the average value of the speed of a fire vehicle, taking into account the condition of the road surface, traffic congestion, and weather conditions is $25-30 \mathrm{~km} / \mathrm{h}$.

It should be noted that as a limitation to mathematical analysis there is no obstacle in the form of congestion, repair of road coverings, accidents, etc.

Thus, using the above source data, it is necessary to create a spatial model of geographic information support of the SFRU in the city of Kharkiv and to develop a geoinformation guide on its basis.

\section{REVIEW OF THE LITERATURE}

The analysis of recent publications on this subject [5-8] showed that the issues mentioned in this study are not described in detail, are general and theoretical, and the main scientific results are not always in the practical implementation.

Many years of experience of domestic and foreign researchers [9-11] prove that it is necessary to develop such a spatial model of the selected territory for further programming of individual tasks of management, monitoring and analysis of geographic data, so that it corresponds with the maximum accuracy to real mapping.

It was revealed that the problem of modernization of fire and rescue services with the use of GIS technologies is theoretically described in more detail in comparison with the summary and superficial analysis of practical use $[12,13]$.

It should be noted that the geoinformation system has been successfully implemented - this is an implementation of information technologies. These technologies allow even non-specialists in a particular area to work productively and make decisions at all stages of the system's life cycle [14].

In addition, existing approaches and technologies for creating information and control systems are not always effective for these specific systems and in some cases require additional research $[15,16]$. 
Speaking about the spatial interpretation of the graph theory models and the variety of algorithms of various scientists based on the classical task of finding the shortest path [17, 18], it has been established that part of the available work is the basis for finding the optimal route.

In addition, it is the first stage in the construction of a network of roads, the so-called graph, however, and this issue requires revisions, additions and practical use.

One example of a similar topic is the sources of foreign experience $[19,20]$, describing the reform of the system of civil defense forces. The proposed approach proves that the most rational means of fire protection is the organization of the VFG, which is based on the principles of certain incentives for benefits, hourly wages and other incentives for fulfilling the tasks. However, this approach does not take into account such criteria as the economic state of the country, the level of organization of fire protection at the legislative and executive levels. Thus, it is impossible to use it to solve the abovementioned tasks.

Consequently, the subject of the study requires additional study, which confirms the relevance and importance of both theoretical and practical results of work.

\section{MATERIALS AND METHODS}

In the theory of graphs, the problem of the shortest path is to find a path between two vertices (or nodes) of the graph that the weight of the edges from which it is composed is minimal. An example can be finding the shortest path between the two points on the road map, where vertices are points, and ribs - roads with weights equal to the time needed to overcome this segment [21].

Known algorithms for solving the problem are:

- Dijkstra's algorithm solving problems with one pair, one input and one output;

- Bellman-Ford's algorithm solves tasks with one input (the weight of the ribs may be negative);

- Floyd-Warshall's algorithm solves the problem for all pairs;

- Johnson's algorithm solves the problem for all pairs and is faster than the Floyd-Warshall's algorithm on sparse graphs;

- the perturbation theory finds (in the worst case) locally the shortest path [22].

In this work, the Dijkstra's algorithm is programmed to construct the shortest path in a graph with an integral weight. Let the size of the graph (Fig. 1) be $|E|=7$, and the number of vertices $|V|=6$.

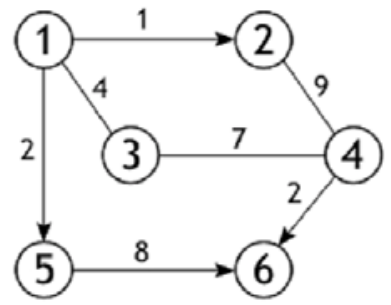

Figure 1 - Weighted graph
This is a weighted graph. Each of its ribs is brought into conformity with some numerical value, so the number of edges lying between a pair of vertices does not necessarily determine the value of the route.

From all the vertices included in the set $V$ we choose one that requires the shortest paths to the other available vertices. Let such be the vertex 1 . The length of the path to all vertices, except for the first, is initially equal to infinity, and to it -0 . The graph has no loops [23].

At the top 1 , exactly 3 neighbors (vertices $2,3,5$ ), to calculate the length of the path to them, weigh the arcs lying between vertices 1 and 2,1, and 3,1 and 5 with the value of the first vertex (with zero):

$$
2 \leftarrow 1+0,3 \leftarrow 4+0,5 \leftarrow 2+0 .
$$

As already noted, the resulting values assigned to the vertices only if they are «better» (less) than those specified now are. Since each of the three numbers is less than infinity, they become new values that determine the length of the path from vertex 1 to vertices 2,3 , and 5 .

The vertex 1 is designated as visited, so the status of the «active» goes to one of its neighbors, namely to the vertex 2 , since it is closest to the previously active vertex (Fig. 2) [23].

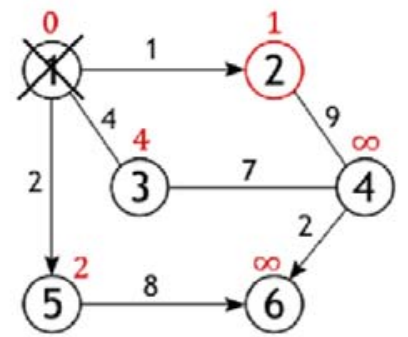

Figure 2 - The result of determining the active vertex 2

In vertex 2 , only one is not considered a neighbor (vertex 1 is designated as visited), the distance to which is 9. It is necessary to calculate the length of the path from the original vertex, for which it is necessary to make the value of the weight of the vertex 2 with the weight of the arc of the vertex 4: $4 \leftarrow 1+9$.

The condition of «brevity» $(10<\infty)$ is executed, therefore, vertex 4 receives a new value of the length of the path.

The vertex 2 ceases to be active, as well as the vertex 1 is removed from the list of not visited. In the same way, all other non-visited vertices and their neighbors are investigated (Fig. 3).

When all the vertices of the graph, or those that are available, will be labeled as visited, then the work of the Dijkstra's algorithm will end and all the paths found will be the shortest. For example, the list of optimal distances between vertex 1 and all others looks like:

$$
1 \rightarrow 1=0,1 \rightarrow 2=1,1 \rightarrow 3=4,1 \rightarrow 4=10,1 \rightarrow 5=2,1 \rightarrow 6=10 .
$$




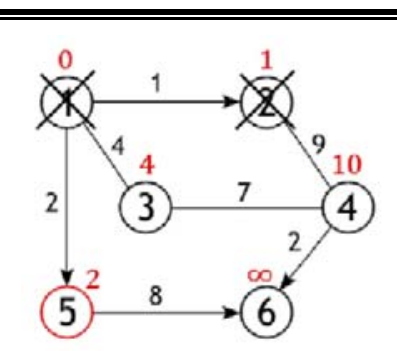

a

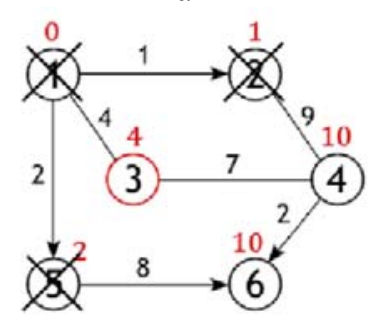

c

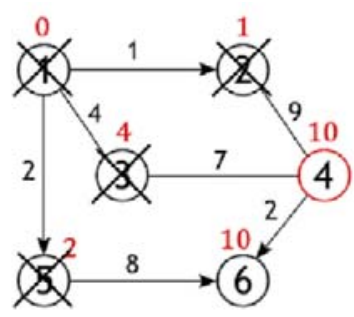

e

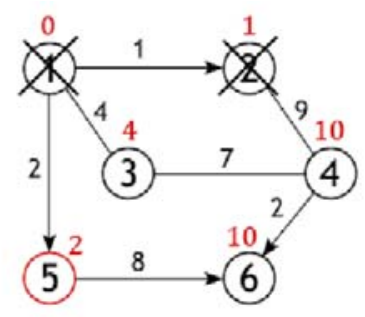

$\mathrm{b}$

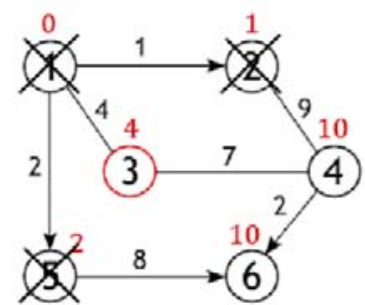

$\mathrm{d}$

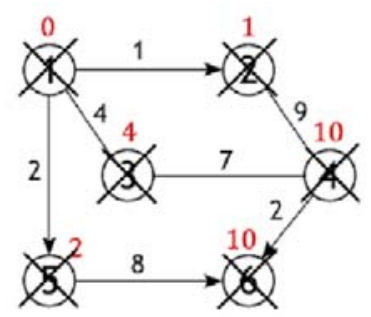

f

Figure 3 - The result of calculating the weight to the vertices:

$\mathrm{a}, \mathrm{b}$ - the result of calculating the weight up to 5 vertices;

c, $d$ - the result of calculating the weight up to 3 vertices;

$\mathrm{e}-$ the result of calculating the weight up to 4 vertices;

$\mathrm{f}$ - the result of the completion of the operation of the Dijkstra's algorithm

Thus, we can conclude that when determining the shortest distance between given vertices using the Dijkstra's algorithm, the main criterion for calculating is the distance from the active vertex to the neighboring vertices.

Consider the mechanism for determining the network of transport routes with modern information tools, namely geoinformation technologies.

It should be noted that the timely arrival of a fire vehicle to the place of the fire depends on the choice of the route of the movement.

The algorithm for finding the optimal transport route is as follows:

- vectorization of the network (graph) of roads;

- determining the length of each element of the graph of its category and width of the roadway;

- taking into account the physic-geographical and meteorological conditions in the area of movement;

- detection of the real situation on the roads: possible traffic congestion and variants of their detour, delays in front of traffic lights at crossroads, different speeds of traffic on separate sections of the city road network, etc.;

(C) Tvoroshenko I. S., Kramarenko O. O., 2019

DOI 10.15588/1607-3274-2019-3-15

- taking into account the protective properties of the area on each element;

- conducting a convolution of indicators and assigning scales to the branches of the roads;

- forming a network of routes;

- the choice of the optimal route.

In addition, it should be borne in mind that the routes found contain route points, which are selected both on the road surface and at a distance from it. The number of them depends on the speed of movement and the nature of the path. The more complex the route, the more there should be route points. The main condition for the correct choice of direction in motion is the continuity of orientation, which ensures that the path follows a given route. Loss of this orientation jeopardizes the performance of the task [24].

It has been established that ESRI's specialized software geoinformation software ArcGIS helps with the implementation of the above tasks. This software package has an additional ArcGIS Network Analyst module, which allows companies and organizations to more effectively work and make profitable strategic decisions. The result of the application of this platform is the reduction of transport costs, the optimal distribution of stops and the definition of the shortest paths between these stops, taking into account limiting factors such as: time intervals (windows), capacity of cars, maximum period spent on the road [25].

To identify the best routes, it is necessary to vectorize the network spatial data, based on which geospatial analysis is possible. It should be noted that before this vectorization it is recommended to identify the axis of roads in a certain area.

To calculate the proximity of spatial objects, ArcGIS uses a geometric distance, namely the Buffer Zone Generation method. Buffer (Buffer) is a zone of precisely defined point width, linear or polygonal spatial object. Because of the buffer generation, a new polygon object, a buffer zone, is created. The task of constructing buffer zones requires the definition of the geometric space of the points of the plane, separated from the set of objects no more than a given distance. A spatial buffer can be generated for proximity analysis. It is used to identify areas and objects that are inside or outside a specific buffer zone. [26]:

The algorithm for buffering a linear spatial object is

- for each segment of polyline, assign the appropriate width of the buffer $b$ (fixed to all lines or weighted);

- each segment of the polylines has an initial vertex $\left(X_{1}, Y_{1}\right)$ and a finite vertex $\left(X_{2}, Y_{2}\right)$. Using these coordinates, calculate the coordinate differences $\Delta x$ and $\Delta y$ between these two endpoints;

- define the coordinates of the endpoints for the parallel buffer lines of each segment of the line on both sides of the segment on the perpendicular of length $b$ by the formulas: 


$$
\begin{aligned}
& x_{1}=X_{1}\left(b * \cos \left[\operatorname{arctg}\left(\frac{\Delta y}{\Delta x}\right)\right]\right), \\
& y_{1}=Y_{1}\left(b * \sin \left[\operatorname{arctg}\left(\frac{\Delta y}{\Delta x}\right)\right]\right), \\
& x_{2}=X_{2}\left(b * \cos \left[\operatorname{arctg}\left(\frac{\Delta y}{\Delta x}\right)\right]\right), \\
& y_{2}=Y_{2}\left(b * \sin \left[\operatorname{arctg}\left(\frac{\Delta y}{\Delta x}\right)\right]\right) .
\end{aligned}
$$

The process of buffering leads to the formation of a new layer in the system, consisting of polygonal data, which are buffer zones.

The resultant polygon table will have identifiers for each polygon created during the buffering process, and additional attributes: buffer width and indication where the polygon is inside the buffer zone or outside the buffer zone.

After constructing buffers, perform operations of selecting objects located in buffer zones, analyzing their attributes.

One of ArcGIS Network Analyst's functions is to add stops to the network model of spatial data, as during a fire vehicle's movement to a fire, the driver should take into account the stops near the location of the nearest FH.

Fig. $4 \mathrm{a}$ shows the route of the fire truck and the stops that it must do on the way to the fire: № 1 - car departing from the SFRU-1, № 2 - the closest FH (this stop may not be foreseen if the tank fire car is filled with water), № 3 - the source of the fire (place of fire). ArcGIS Network Analyst provides the ability to view the Directions dialog (Fig. 4b).

It should be noted that with the help of this module it is possible to minimize the influence of external factors, such as accidents or traffic jams on laying the optimal transport route. Having pre-tagged them on the map, the new route will be calculated taking into account the relevant barriers (Fig. 4c).

During the design of the optimal route, geoinformation analysis tools enable the inclusion of dynamically changing spatial data regarding the traffic load of the motor transport along the city transport network with the online ArcGIS Online portal (Fig. 5).

It should be noted that the traffic data is updated every five minutes, so it can be used when laying a route for a rescue unit. In addition, due to the dynamism of the data, it is possible to avoid overloading by road transport by reducing the time of arrival of the fire truck to the place of the call.

After analyzing ArcGIS Online, it is established that the speed is reflected in percentages and depends on the speed of transport:

- green (fast) $-85 \%-100 \%$;

- yellow (average) - 65\%-85\%;

- orange (slow) - $45 \%-65 \%$;

- red (slow, frequent stops) $-0 \%-45 \%$.

(C) Tvoroshenko I. S., Kramarenko O. O., 2019

DOI 10.15588/1607-3274-2019-3-15
Using the specified output data, taking into account assumptions and limitations, user interface settings have been made.

The software development toolkit can be a programming language built into the ArcGIS - VBA or Python software platform. In this paper, the algorithm of Dijkstra's and Floyd-Warshall's implemented using the Python language, and a geoinformation guide for the SFRU man-

\begin{tabular}{|c|c|c|c|c|c|}
\hline \multicolumn{3}{|c|}{ Route: Graphic Pick 1 - Graphic Pick 3} & \multirow{2}{*}{$1401,3 \mathrm{~m}$} & \multirow{2}{*}{ < $1 \min$} & Map \\
\hline 1: & & Start at Graphic Pick 1 & & & Map \\
\hline 2: & & Go east on 362904997900046 toward 362904997901241 & $43 \mathrm{~m}$ & & Map \\
\hline & [+] & Make sharp right on 362904997901241 & $43,1 \mathrm{~m}$ & & Map \\
\hline 4: & & Arrive at Graphic Pick 2, on the left & & & Map \\
\hline 5: & & Depart Graphic Pick 2 & & & \\
\hline 6: & & Continue southwest on 362904997901241 & $327 \mathrm{~m}$ & & Man \\
\hline $\bar{z}:$ & [+] & Make sharp left on 362904997900468 & $228,7 \mathrm{~m}$ & & Mas \\
\hline 8: & [+] & Turn right & $272,4 \mathrm{~m}$ & & Map \\
\hline 2: & {$[+]$} & Turn right on 362904997900467 & $373.7 \mathrm{~m}$ & & Map \\
\hline 10: & {$[+]$} & Turn left & $113,5 \mathrm{~m}$ & & Map \\
\hline 11: & & $\begin{array}{l}\text { Finish at Graphic Pick } 3 \text {, on the left } \\
\text { Total time: }<1 \mathrm{~min} \\
\text { Total distance: } 1401,3 \mathrm{~m}\end{array}$ & & & Map \\
\hline
\end{tabular}
ager - VBA [25].

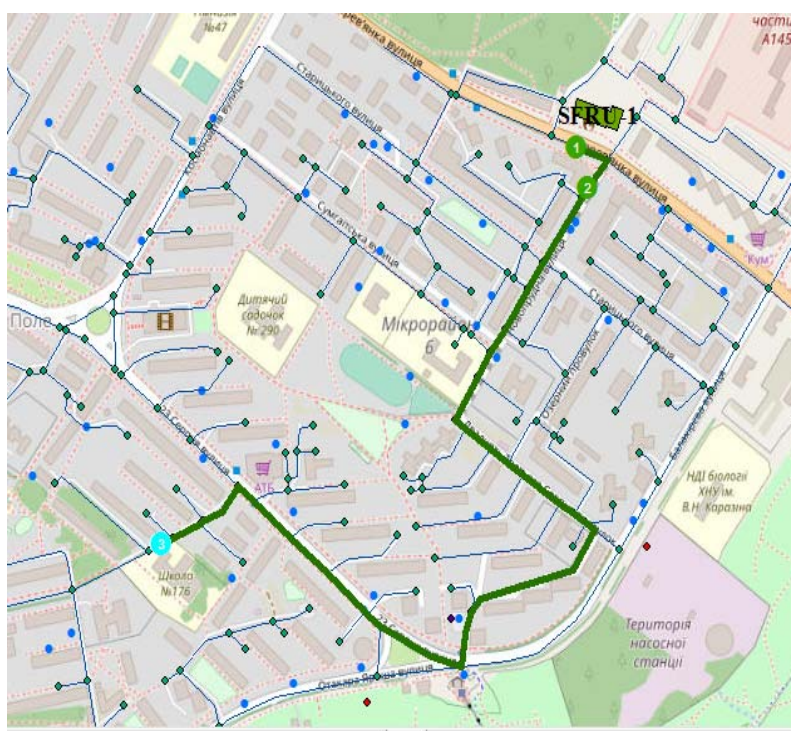

a

b

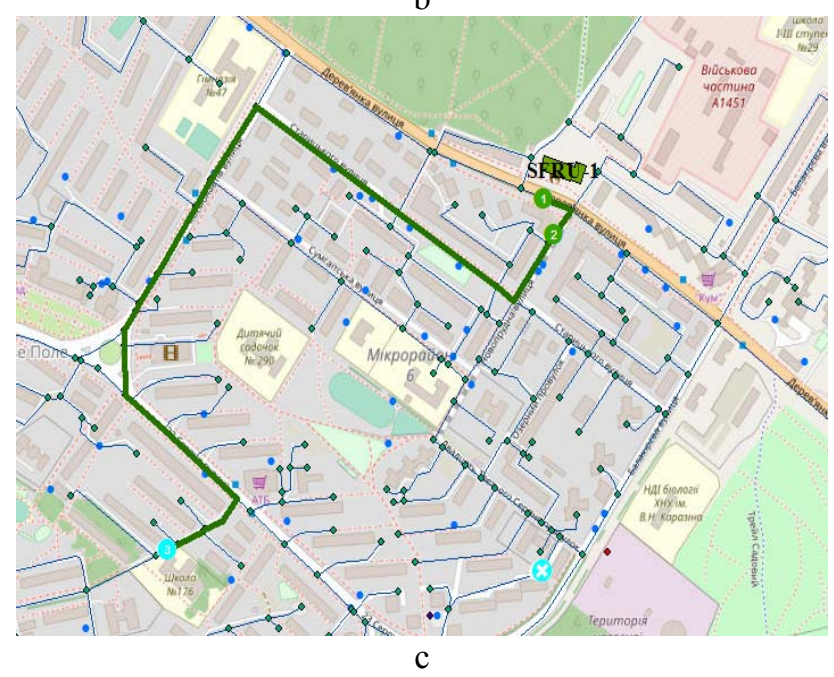

Figure 4 - Network Analyst Result:

a - view of the initial transport route;

$\mathrm{b}$ - appearance of the Directions dialog;

$\mathrm{c}-\mathrm{a}$ new alternative transport route 


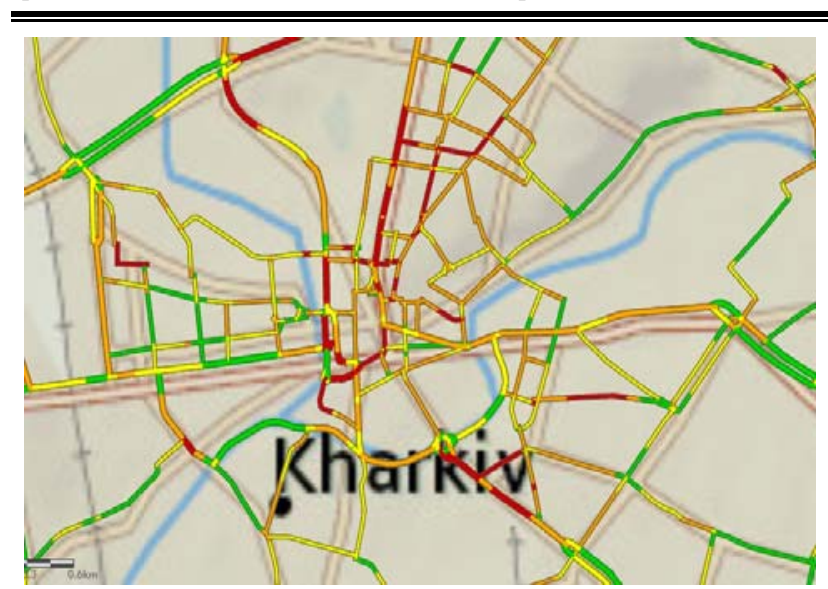

Figure 5 - Transport network load

It should be noted that the main advantage of development in the environment of the IDLE in the language Python mathematical algorithm Dijkstra's is graphical visualization, but the search for the shortest path occurs without detail in the time form, as well as the traversed path between the input points. Unlike the previous, the Floyd-Warshall's algorithm allows you to get distances between vertices, calculating and determining the shortest path. However, these algorithms and their implementation do not visualize the direct location of the points. Thus, it was decided to develop a geoinformation guide using the ArcGIS platform and the VBA programming language.

\section{EXPERIMENTS}

The testing of the developed geoinformation directory is performed in a certain logical sequence of actions. At the first stage of work, entering the address of the place of the fire, the corresponding object automatically begins to be highlighted on the map. The next stage is the construction of buffer zones (taking into account all restrictions and assumptions, it is decided to build 500-meter buffer zones in order to identify the nearest FH).

By constructing buffer zones, it is necessary to determine which $\mathrm{FH}$ have fallen into their zone of action. The Geoinformation Analysis tool is the Overlay feature. It should be noted that the key elements of the spatial object overlay are the input layer, the overlay layer, and the source layer.

In addition, the Overlay function cuts spatial objects in the input layer where they overlap with spatial objects of the overlay layer [27].

New areas are created at the intersection of landfills. If the input layer contains lines, then they are broken in places where they are crossed by polygons. These new spatial objects are stored in the original layer. The input layer does not change.

The attributes of spatial objects in the overlay layer are assigned to new spatial objects in the output layer, along with the source attributes of the input layer.

Conceptually, the tools for imposing spatial objects are similar, they differ only [28]:

- types of spatial objects;

- the ability to simultaneously apply several layers;
- input and overlay objects remaining in the original layer.

Given the features of the input and output data, the Intersection function is applied.

The basis for this function is the pre-built layer khabuíld_spaero_500_Buffér1 and the FH layer.

After completing the intersection function, a new layer khabuild spaero 500 Buffer1 intersect has been received and attribute data for the hydrants in the buffer zones data area is filled. Unfortunately, not all hydrants entering the radius of a conventionally taken distance of $500 \mathrm{~m}$ are repaired. It should be noted that using the classification method, visual and statistical data on nonworking hydrants are obtained.

Consider the practical application of the developed geoinformation guide. Let the address of the fire - Khalturina Street, 19. Automatically built buffer zone detected FH that fell within a radius of $500 \mathrm{~m}$. The total amount of FH was 48 pcs, of which 26 pcs - FH are in working condition, and 22 pcs. $\mathrm{FH}$ is not working, i.e. $54 \%$ and $46 \%$, respectively. The obtained data confirm that the lack of FH enhances the problem of rapid response to a dangerous event. To partially compensate for the identified drawback, a number of alternative routes and the optimal route to the specified object were found, minimizing the time costs for the arrival of the SFRU team to the place of the emergency.

Thus, after carrying out the above-mentioned operations, which are pre-programmed, we will obtain the operating numbers of $\mathrm{FH}$ that fall into the zone of operation of the built 500-meter buffer. Due to the associated databases of the databases of the SFRU and the addresses of the locations of the fires (item B), the nearest SFRU (item A) is automatically determined.

Consequently, with the filled fields of items A and B, using the additional Network Analyst module, alternate routes are displayed, which are displayed in the corresponding fields of the «Geoinformational_assistant» form and provided with the recommended route (with minimal time expenditures).

It should be noted that you could additionally see the result of calculating the optimal transport route by clicking on the button on the toolbar Network Analyst.

A map-incision and the specified lengths of the corresponding parts of the road accompany changing the direction of movement in this sheet. This allows the driver to directly find the direction of each maneuver

After analyzing the algorithm for finding the shortest path taking into account the category of the road, it has been established that the geoinformation guide developed helps to find the set of alternative routes. It also determines, depending on the quality of the road surface, the time of arrival of the car to object B and displays the recommended route with the minimum time on the screen.

An example of using this software is shown in Fig. 6. 


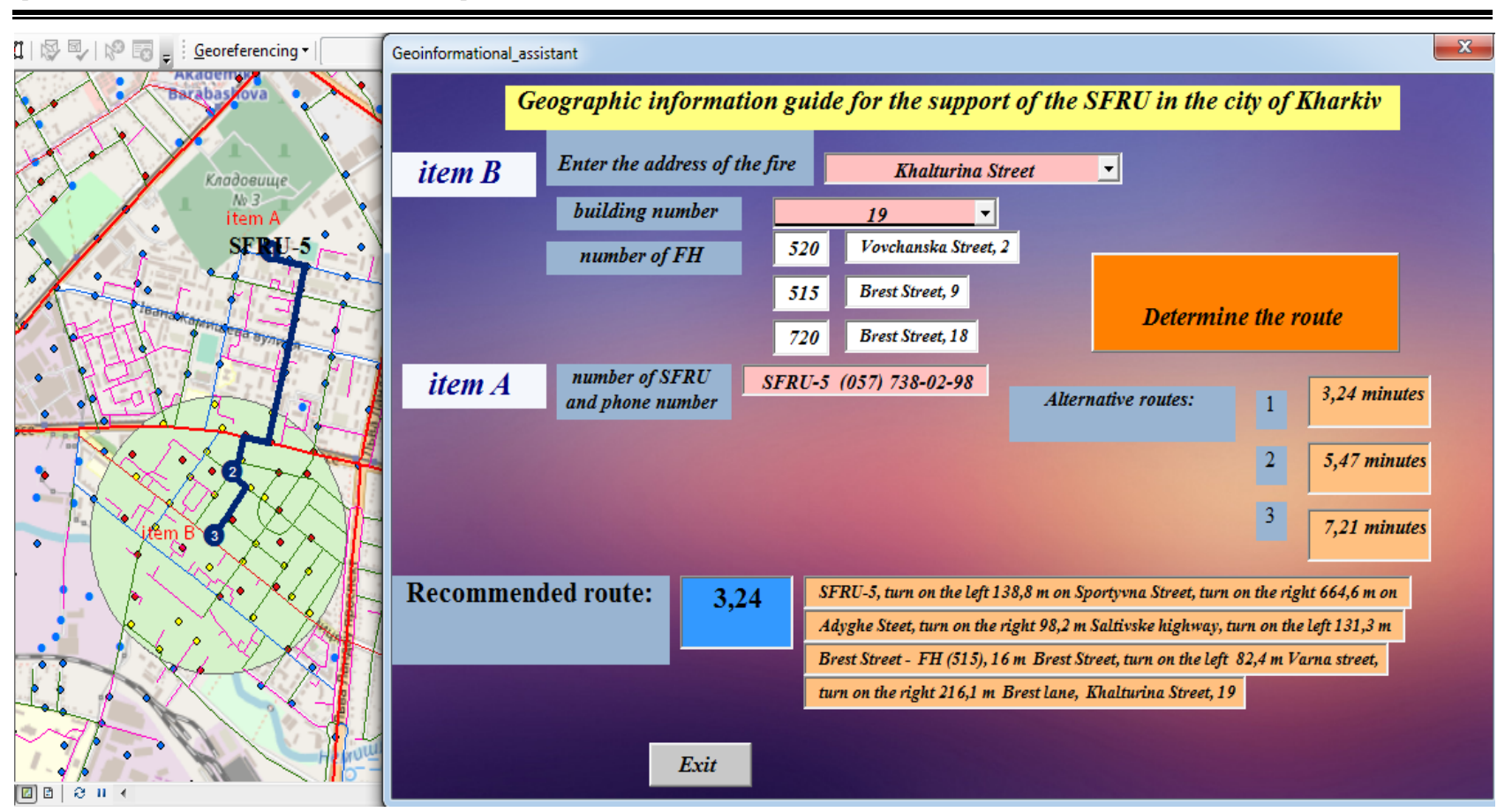

Figure 6 - The result of testing the geoinformation directory

\section{RESULTS}

Provision of operational firefighting is an aggregate task that includes a combination of a set of necessary criteria, namely: type of highways, road surface quality, and functional fire trucks combined with the necessary technological support, objectively designed route list and operational actions of firefighters.

One of the most important criteria is a well-designed road route. To determine the optimal transport route, the means of both mathematical and geoinformation analysis are analyzed. It is established that the corresponding types of analysis are closely interrelated, since in the basis of any geoinformation analysis basic methods of mathematical analysis are laid.

On the example of the theory of graphs, the shortest path between the nodes of the graph with the weight of each edge is programmed.

Having analyzed the obtained data, it is concluded that today, unfortunately, there is no reliable data as to which algorithm is the basis of the Network Analyst software module, but one can make assumptions about its similarity with the Dijkstra's algorithm.

An important aspect when solving the problems of this class in systems of large dimension is to evaluate their complexity according to the criteria of time and computing resources expenditure. To determine the complexity of process modeling, that is, the processing time of the input data prior to the output of the result on the screen, it is advisable to select several test cases of the system with a different amount of source information [29, 30].

Suppose B corresponds to the address of the fire Khalturina Street, 19, the time of data processing to find the corresponding SFRU, the numbers and addresses of the $\mathrm{FH}$, the number of alternative routes and the definition of the recommended route is $3.05 \mathrm{~s}$ (Table 1).

(C) Tvoroshenko I. S., Kramarenko O. O., 2019

DOI 10.15588/1607-3274-2019-3-15
Similarly, other experimental cases (test cases) for a mathematical and geoinformation algorithm were investigated, the time of data processing was determined depending on the variability of the input parameters. It is found that the analyzed types of analysis show similar results, but if one needs to be selected, and then the answer is obvious, since the geographic information platform provides the opportunity for visualization, modeling and synthesis of information.

Table 1 - System test results

\begin{tabular}{|c|c|c|}
\hline $\begin{array}{c}\text { Number } \\
\text { of test case }\end{array}$ & $\begin{array}{c}\text { Number of processed } \\
\text { parameters }\end{array}$ & $\begin{array}{c}\text { Time of data } \\
\text { processing, } \mathbf{s}\end{array}$ \\
\hline 1 & 20 & 3.74 \\
\hline 2 & 18 & 3.54 \\
\hline 3 & 16 & 3.36 \\
\hline 4 & 17 & 3.44 \\
\hline 5 & 13 & 2.98 \\
\hline 6 & 15 & 3.15 \\
\hline 7 & 12 & 2.91 \\
\hline $\mathbf{8}$ & $\mathbf{1 4}$ & $\mathbf{3 . 0 5}$ \\
\hline 9 & 11 & 2.81 \\
\hline 10 & 9 & 2.68 \\
\hline 11 & 10 & 2.73 \\
\hline 12 & 7 & 2.54 \\
\hline
\end{tabular}

In the course of the research, it was discovered that there is no need to introduce additional requirements for software implementation and hardware, the program can work on personal computers, which is extremely important in practical implementation.

The work is done with the use of modern geoinformation technologies and is an effective means of making decisions, modeling and evaluating real processes.

It makes it possible to increase the likelihood of decision-making at a reasonable time for assessing the states 
of complex objects, to reduce the influence of the subjective factor on the result of the system.

Thanks to the use of specialized ArcGIS software modules, the search for the optimal route has been made. There are also stops and alternative routes in case of road surface repairs, congestion or accidents. To improve the accuracy of the results, additional data from the ArcGIS Online cloud infrastructure has been applied to the traffic load on the territory of the city of Kharkiv. Consequently, the use of geoinformation analysis tools will be able to provide the SFRU with important, dynamically changing data, affecting the reduction of the arrival time of the operational brigade to the place of the fire.

\section{DISCUSSION}

In the above example, while finding the recommended optimal route for the arrival of the SFRU vehicle to a fire location, the geoinformation toolkit allows you to display a dynamic-variable platform for analysis (ArcGIS Online, which contains constantly updated data). Also, having pre-made an automated analysis of the search for working $\mathrm{FH}$, which provides an opportunity to predict the stops.

By combining different spatial and attribute information, it is possible to search for an optimal transport route for up to five seconds. The user is only required to enter the location of the fire and the recommended route will automatically be displayed on the map (taking into account the category of roads), while the nearest working $\mathrm{FH}$ are highlighted on the map, the time of arrival to the place of the fire and a detailed route list.

Thus, the methods and tools of geoinformation analysis provide the opportunity to quickly determine the optimal path in combination with the reflection of the results in a real environment - the map.

It should be noted that the effectiveness of fire fighting in the city of Kharkiv, according to expert estimates, increased by $25 \%$. At the expense of the developed software, by which, by entering the address of the origin of the hearth, it is possible to instantly identify the SFRU, which serves the corresponding address, in the radius of $500 \mathrm{~m}$ from the fire to find the existing $\mathrm{FH}$. Also, show the alternative routes of the arrival of the fire truck and highlight the recommended route with the appropriate detail, the so-called route sheet (Fig. 6).

In addition, the developed spatial model of geographic information support of the SFRU of the city of Kharkiv was adapted for the urban type of Kotelva Poltava region. The received software of geographic information support of the SFRU of the settlement of the city type Kotelva was used by the Kotelva district sector of the Main Directorate of the SES of Ukraine in the Poltava region. According to expert assessments of the management of this management, the development has improved the effectiveness of firefighting by $20 \%$, as evidenced by the act of using the results of work.

\section{CONCLUSIONS}

During the work, the use of interdisciplinary knowledge is combined: methods of system analysis and synthesis, modeling, programming in VBA and Python languages, higher mathematics, combinatory, geodesy, topography, geoinformatics, and a method for determining computational time.

The purpose of the work is achieved. The software of the multifunctional geographic information manual for the automatic determination of the optimal transport route using modern geoinformation technologies for increasing the firefighting efficiency in the city of Kharkiv has been developed.

The scientific novelty of the obtained results is that the spatial model of the city of Kharkiv was further developed due to the use of geoinformation and mathematical analysis methods during the development of software, which allowed taking into account a set of important criteria. In addition, the spatial model of geographic information support of the SFRU in Kharkiv has been improved by taking into account and applying the road distribution criteria according to the categories, which has enabled the development of an effective software platform for rapid response.

The practical significance of the results obtained is that they are real and are used by the Kotelva district sector of the Main Directorate of the SES of Ukraine in the Poltava region to increase the firefighting efficiency by determining the optimal route of the arrival of the fire brigade with the help of geoinformation technologies.

Prospects for further research are:

- expansion of the embedded geoinformation analysis of the mathematical basis, combining the algorithms of Dijkstra's and Floyd-Warshall's into an additional module;

- the inclusion of an interactive ArcGIS Online card, which reflects the actual condition of the traffic load, and the possibility of using the relevant data when designing the recommended route;

- developing an application for Android and IOS platforms with the possibility of compact use of the geographic information directory;

- implementation of the results of the work of the Main Directorate of the SES of Ukraine in the Kharkiv region.

\section{ACKNOWLEDGEMENTS}

The experts of the Kotelva district sector of the Main Directorate of the SES of Ukraine in the Poltava region and the Main Directorate of the SES of Ukraine in the Kharkiv region provided expert assessments of the results.

\section{REFERENCES}

1. Tvoroshenko I. S., Mgebrova V. R., Belyj V. V. Prakticheskie aspekty primenenija sovremennyh geoinformacionnyh sistem dlja sozdanija municipal'noj geoinformacionnoj sistemy goroda Har'kova, Sbornik HUVS, 2015, No. 7, pp. 65- 


\section{$70 . \quad$ Rezhim dostupa \\ http://nbuv.gov.ua/UJRN/soi 2015717}

2. Pro zatverdzhennja Planu zahodiv shhodo realizacii' Strategii' reformuvannja systemy Derzhavnoi' sluzhby Ukrai'ny z nadzvychajnyh sytuacij [Elektronnyj resurs]. Rezhym dostupu : https://zakon.rada.gov.ua/rada/shosh/v0132388-17

3. Pro zatverdzhennja Kompleksnoi' programy rozvytku cyvil'nogo zahystu ta pidvyshhennja rivnja publichnoi' bezpeky u misti Harkovi na 2018-2022 roky [Elektronnyj resurs]. Rezhym dostupu : http://kharkiv.rocks/reestr/663881

4. Ukrai'ns'kyj naukovo-doslidnyj instytut cyvil'nogo zahystu (UkrNDICZ) [Elektronnyj resurs]. Rezhym dostupu : http://undicz.dsns.gov.ua/ua/STATISTIKA-POZHEZH.html

5. Maiorov A. A. Modern Development of Geoinformatics, European Researcher, 2014, Vol. 82, No. 9 (1), pp. 1620 1627. DOI: $10.13187 /$ er.2014.82.1620

6. Kuzhelev P. D. Geoinformation Technology for the Control of Transportation Objects, European Journal of Technology and Design, 2013, Vol. 2, No. 2, pp. 97-102. DOI: 10.13187/ejtd.2013.2.97

7. Markelov Vladimir Geoinformation Modeling in Logistics, European Journal of Technology and Design, 2013, Vol. 2, No. 2, pp. 129-133. DOI: 10.13187/ejtd.2013.2.129

8. Ibisch P. L., Hoffmann M. T., Kreft S. et al. A global map of roadless areas and their conservation status, Science, 2016, Vol. 354, No. 6318, pp. 1423-1427. DOI: 10.1126/science.aaf7166

9. Tsvetkov V. Ya. Systems analysis in geoinformatics, European Journal of Technology and Design, 2013, Vol. 2, No. 2, pp. 135-140. DOI: 10.13187/issn.2310-0133

10. Lobanov A. A. Digital Simulation in the Geosciences, European Researcher, 2014, Vol. 82, № 9 (1), pp. 16111619. DOI: $10.13187 /$ er.2014.82.1611

11. Karmanova N. A., Jakushenko S. A., Manjashin D. A., Malyshev A. K. Mnogoparametricheskij poisk optimal'nyh marshrutov dvizhenija podvizhnyh ob\#ektov v uslovijah destabilizirujushhih faktorov, Informacija $i$ kosmos, 2016, No. 4, pp. 144-151. Rezhim dostupa http://openbooks.ifmo.ru/ru/article/16339/mnogoparametricheskiy_poisk_optimalnyh_marshrutov_dvizheniya_podvizhny h_obektov_v_usloviyah_destabiliziruyuschih_faktorov.html

12. Lévy B., Schwindt E. Notions of optimal transport theory and how to implement them on a computer, Computers \& Graphics, 2018, Vol. 72, pp. 135-148. DOI: 10.1016/j.cag.2018.01.009

13. Cui J., Zhang Y., Cai Z. et al. Securing display path for security-sensitive applications on mobile devices, Computers Materials and Continua, 2018, Vol. 55, No. 1, pp. 17-35. DOI: https://doi.org/10.3970/cmc.2018.055.017

14. Tvoroshenko I. S., Tabashnyk V. A. Rozrobka prostorovoi' modeli geoinfor-macijnoi' pidtrymky ljudej z obmezhenymy mozhlyvos-tjamy, shho peresuvajut'sja na invalidnyh koljaskah, u misti Harkovi, Zbirnyk naukovyh prac' HNUPS 2018, Vyp. 1 (55), pp. 122-128. DOI: 10.30748/zhups.2018.55.17

15. GIS for Fire Station Locations and Response Protocol Esri [Electronic resource]. Access mode : https://www.esri. com/library/whitepapers/pdfs/gis-for-fire.pdf

16. Hesse G., Lorenz M. Conceptual Survey on Data Stream Processing Systems, Parallel and Distributed Systems : 21st International Conference IEEE (ICPADS), Melbourne, 1417 Dec. 2015 : proceedings. Melbourne, IEEE, 2015, pp. 797-802. DOI: 10.1109/ICPADS.2015.106

17. Schmitzer B. A sparse multiscale algorithm for dense optimal transport, Journal of Mathematical Imaging and Vision,
2016, Vol. 56(2), pp. 238-259. DOI: 10.1007/s10851-0160653-9

18. Morduhov M. A., Samsonov M. A Ispol'zovanie instrumentov transportnogo modelirovanija dlja prognozirovanija izmenenij dorozhno-transportnoj situacii pri rekonstrukcii ulichno-dorozhnoj seti, Organizacija $i$ bezopasnost' dorozhnogo dvizhenija, X Mezhdunarodnaja nauchnoprakticheskaja konferencija, posvjashhennaja 85-letiju so dnja rozhdenija d.t.n., professora L. G. Reznika : $v 2$ tomah, Tjumen', 16 marta 2017 g. : tezisy dokladov, Tjumen', Tjumenskij industrial'nyj universitet, 2017, pp. 425-429.

19. Ratajczyk B. The role and place of volunteer fire service in the national rescue and firefighting system, Bezpieczeństwo $i$ Technika Pożarnicza, 2016, Vol. 43, Issue 3, pp. 3-20. DOI: 10.12845/bitp.43.3.2016.1

20. Wójcik Grzegorz, Surowicz Dawid, Kuźnicki Mateusz, Myślak Marek The state of knowledge of qualified first aid among firefighters of the national and volunteer fire service, pp. 102-110. DOI: 10.12845/bitp.45.1.2017.8

21. Chen B., Shi Y. C., Zhang J. et al. Most reliable path-finding algorithm for maximizing on-time arrival probability, Transportmetrica B: Transport Dynamics, 2017, Vol. 5, No. 3, pp. 253-269. DOI: 10.1080/21680566. 2016.1169953

22. Andrew V. Goldberg Point-to-Point Shortest Path Algorithms with Preprocessing, Theory and Practice of Computer Science : 33rd Conference on Current Trends in Theory and Practice of Computer Science, Harrachov, Czech Republic, 20-26 January 2007 : proceedings. Harrachov, SOFSEM, 2007, pp. 88-102. DOI: 10.1007/978-3-54069507-3 6

23. Sun Y., Yu X., Bie R. et al. Discovering time-dependent shortest path on traffic graph for drivers towards green driving, Journal of Network and Computer Applications, 2017, Vol. 83, pp. 204-212. DOI: 10.1016/j.jnca.2015.10.018

24. Liang Shen, Hu Shao, Long Zhang et al. The Global Optimal Algorithm of Reliable Path Finding Problem Based on Backtracking Method, Mathematical Problems in Engineering, 2017, Vol. 2017, pp. 1-10. DOI: 10.1155/2017/4586471

25. Imzaem Abdulkareem, Ammar A. Shubber, Asseel Sabah Multi-criteria decision making to select the best monorail route, Global Journal of Engineering Science and Research Management, 2018, pp. 16-32. DOI: 10.5281 /zenodo. 1255758

26. Tvoroshenko I. S., Kramarenko O. O. Osoblyvosti zastosuvannja geoinforma-cijnyj tehnologij pid chas rozrobky merezhi prostorovyh ob'jektiv operatyvnogo pozhezhogasinnja v misti Harkovi, Geoinformacijni tehnologii' $u$ terytorial'nomu upravlinni ta ekspertnyh doslidzhennjah: pravovi, organizacijni, tehnichni problemy: IV Mizhnarodna naukovo-praktychna konferencija, L'viv, 46 zhovtnja 2017 r. : tezy dopovidej. L'viv, L'vivs'ka politehnika, 2017, pp. 159-163.

27. Tvoroshenko I. S., Shevchenko A. R. Udoskonalennja prostorovoi' merezhi navchal'nyh zakladiv mista Sjevjerodonec'ka na osnovi geoinformacijnogo analizu, Systemy obrobky informacii', 2018, Vyp. 1 (152), pp. 46-52. DOI: $10.30748 /$ soi.2018.152.07

28. Tvoroshenko I. S., Mgebrova V. R., Bilyj V. V. Praktychni aspekty stvorennja vyhidnoi' informacii' dlja provedennja geoinformacijnogo analizu u sferi upravlinnja neruhomistju, Zbirnyk naukovyh prac' HUPS, 2016, Vyp. 1 (46), pp. $107-$ 111. Rezhym dostupu http://nbuv.gov.ua/UJRN/ZKhUPS_2016_1_26 
29. Tvoroshenko I. S. Analiz processov prinjatija reshenij v intellektual'nyh sistemah, Sistemy obrabotki informacii, 2010, Vyp. 2 (83), pp. 248-253. Rezhim dostupa : http://nbuv.gov.ua/UJRN/soi 2010256

30. Kucherenko Je. I., Kucherenko V. Je., Glushenkova I. S., Tvoroshenko I. S. Metody, modeli ta informacijni tehnologii' ocinjuvannja staniv skladnyh ob'jektiv : monografija. Harkiv, HNAMG ; HNURE, 2012, 278 p. Rezhym dostupu : http://eprints.kname.edu.ua/29457/

Received 04.03.2019. Accepted 07.06.2019.

УДК 004.9

\section{ПРОГРАМНЕ ЗАБЕЗПЕЧЕННЯ ВИЗНАЧЕННЯ ОПТИМАЛЬНОГО МАРШРУТУ ЗАСОБАМИ ГЕОІНФОРМАЦІЙНИХ ТЕХНОЛОГІЙ}

Творошенко І. С. - канд. техн. наук, доцент кафедри інформатики Харківського національного університету радіоелектроніки, Харків, Україна

Крамаренко О. О. - магістр за спеціальністю геодезія та землеустрій, інженер-землевпорядник товариства $з$ обмеженою відповідальністю «Геодезично-вишукувальний центр», Харків, Україна.

\section{АНОТАЦЯ}

Актуальність. Актуальність даної роботи полягає у розробці програмного забезпечення багатофункціонального геоінформаційного довідника підтримки державної пожежно-рятувальної частини засобами сучасних геоінформаційних технологій. Об’єктом дослідження є інфраструктура міста Харкова.

Мета. Метою дослідження є розробка програмного забезпечення багатофункціонального геоінформаційного довідника автоматичного визначення оптимального транспортного маршруту засобами сучасних геоінформаційних технологій для підвищення ефективності пожежогасіння в місті Харкові.

Метод. Під час дослідження використано загальнонаукові методи: картографічний, системного аналізу та синтезу для визначення та узагальнення теоретико-методичних засад державних будівельних норм, моделювання, вищої математики, комбінаторики, а також спеціальні методи математичного та геоінформаційного аналізу. У роботі застосовано програмну платформу ArcGIS для створення, управління, інтеграції, аналізу та поширення просторових даних. Використано методи: програмування на мовах VBA та Руthon, геодезії, топографії, геоінформатики, визначення обчислювального часу.

Результати. Результати, що отримані у процесі виконання даного дослідження, а саме: методичне, алгоритмічне та програмне забезпечення багатофункціонального геоінформаційного довідника, мають практичну значимість, $\epsilon$ реальними та використовуються Котелевським районним сектором Головного управлінням Державної служби України 3 надзвичайних ситуацій у Полтавській області, а також можуть бути застосованими Головним управлінням Державної служби України 3 надзвичайних ситуацій у Харківській області для автоматичного визначення оптимального маршруту оперативного прибуття пожежної бригади за допомогою геоінформаційних технологій, інструментарію математичного та геоінформаційного аналізу.

Висновки. Отримала подальшого розвитку просторова модель міста Харкова за рахунок використання під час розробки програмного забезпечення методів геоінформаційного та математичного аналізу, що дозволило врахувати сукупність важливих критеріїв. Удосконалено просторову модель геоінформаційної підтримки державних пожежно-рятувальних частин міста Харкова за рахунок врахування та застосування критерію розподілу доріг відповідно до категорій, що дозволило розробити ефективну програмну платформу для швидкого реагування. Перспективи подальших досліджень передбачають розроблення застосунку для платформ Android та IOS із можливістю компактного використання геоінформаційного довідника, а також залучення інтерактивної карти ArcGIS Online, що відображає реальний стан завантаженості дороги і можливості застосування відповідних даних при проектуванні рекомендованого маршруту.

KEYWORDS: теорія графів, аналіз просторових даних, оптимальний транспортний маршрут, геоінформаційна система, буферна зона, обчислювальний час, сучасні геоінформаційні технології, алгоритм, інфраструктура міста.

УДК 004.9

\section{ПРОГРАММНОЕ ОБЕСПЕЧЕНИЕ ОПРЕДЕЛЕНИЯ ОПТИМАЛЬНОГО МАРШРУТА СРЕДСТВАМИ ГЕОИНФОРМАЦИОННЫХ ТЕХНОЛОГИЙ}

Творошенко И. С. - канд. техн. наук, доцент кафедры информатики Харьковского национального университета радиоэлектроники, Харьков, Украина.

Крамаренко А. А. - магистр по специальности геодезия и землеустройство, инженер-землеустроитель общества с ограниченной ответственностью «Геодезическо-исследовательский центр», Харьков, Украина.

\section{АННОТАЦИЯ}

Актуальность. Актуальность данной работы заключается в разработке программного обеспечения многофункционального геоинформационного справочника поддержки государственной пожарно-спасательной части средствами современных геоинформационных технологий. Объектом исследования является инфраструктура города Харькова.

Цель. Целью исследования является разработка программного обеспечения многофункционального геоинформационного справочника автоматического определения оптимального транспортного маршрута средствами современных геоинформационных технологий для повышения эффективности пожаротушения в Харькове. 
Метод. В ходе исследования использованы общенаучные методы: картографический, системного анализа и синтеза для определения и обобщения теоретико-методических основ государственных строительных норм, моделирования, высшей математики, комбинаторики, а также специальные методы математического и геоинформационного анализа. В работе применено программную платформу ArcGIS для создания, управления, интеграции, анализа и распространения пространственных данных. Использованы методы: программирования на языках VBA и Python, геодезии, топографии, геоинформатики, определение вычислительного времени.

Результаты. Результаты, полученные в процессе выполнения данного исследования, а именно: методическое, алгоритмическое и программное обеспечение многофункционального геоинформационного справочника, имеют практическую значимость, являются реальными и используются Котелевским районным сектором Главного управления государственной службы Украины по чрезвычайным ситуациям в Полтавской области. Также могут быть примененными Главным управлением Государственной службы Украины по чрезвычайным ситуациям в Харьковской области для автоматического определения оптимального маршрута оперативного прибытия пожарной бригады с помощью геоинформационных технологий, инструментария математического и геоинформационного анализа.

Выводы. Получила дальнейшее развитие пространственная модель города Харькова за счет использования при разработке программного обеспечения методов геоинформационного и математического анализа, что позволило учесть совокупность важных критериев. Усовершенствована пространственная модель геоинформационной поддержки государственных пожарно-спасательных частей города Харькова за счет учета и применения критерия распределения дорог в соответствии с категориями, что позволило разработать эффективную программную платформу для быстрого реагирования. Перспективы дальнейших исследований предусматривают разработку приложения для платформ Android и IOS с возможностью компактного использования геоинформационного справочника, а также привлечение интерактивной карты ArcGIS Online, отражающей реальное состояние загруженности дороги и возможности применения соответствующих данных при проектировании рекомендованного маршрута.

КЛЮЧЕВЫЕ СЛОВА: теория графов, анализ пространственных данных, оптимальный транспортный маршрут, геоинформационная система, буферная зона, вычислительное время, современные геоинформационные технологии, алгоритм, инфраструктура города.

\section{ЛІТЕРАТУРА / ЛИТЕРАТУРА}

1. Творошенко И. С. Практические аспекты применения современных геоинформационных систем для создания муниципальной геоинформационной системы города Харькова / И. С. Творошенко, В. Р. Мгеброва, В. В. Белый // Сборник ХУВС. - 2015. - № 7. - С. 65-70. Режим доступа: http://nbuv.gov.ua/UJRN/soi 2015717

2. Про затвердження Плану заходів щодо реалізації Стратегії реформування системи Державної служби України 3 надзвичайних ситуацій [Електронний ресурс]. - Режим доступу : https://zakon.rada.gov.ua/rada/show/v0132388-17

3. Про затвердження Комплексної програми розвитку цивільного захисту та підвищення рівня публічної безпеки у місті Харкові на 2018-2022 роки [Електронний ресурс]. - Режим доступу : http://kharkiv.rocks/reestr/ 663881.

4. Український науково-дослідний інститут цивільного захисту (УкрНДІЦЗ) [Електронний ресурс]. - Режим доступу : http://undicz.dsns.gov.ua/ua/STATISTIKAPOZHEZH.html

5. Maiorov A. A. Modern Development of Geoinformatics A. A. Maiorov // European Researcher. - 2014. - Vol. 82, № 9 (1). - P. 1620-1627. DOI: 10.13187/er.2014.82.1620

6. Kuzhelev P. D. Geoinformation Technology for the Control of Transportation Objects / P. D. Kuzhelev // European Journal of Technology and Design. - 2013. - Vol. 2, № 2. P. 97-102. DOI: 10.13187/ejtd.2013.2.97

7. Markelov Vladimir Geoinformation Modeling in Logistics Vladimir Markelov // European Journal of Technology and Design. - 2013. - Vol. 2, № 2. - P. 129-133. DOI: 10.13187/ejtd.2013.2.129

8. A global map of roadless areas and their conservation status / [P. L. Ibisch, M. T. Hoffmann, S. Kreft et al.] // Science. 2016. - Vol. 354, № 6318. - P. 1423-1427. DOI: 10.1126/science.aaf7166

9. Tsvetkov V. Ya. Systems analysis in geoinformatics / V. Ya. Tsvetkov // European Journal of Technology and Design. - 2013. - Vol. 2, № 2. - P. 135-140. DOI $10.13187 /$ issn. $2310-0133$

(C) Tvoroshenko I. S., Kramarenko O. O., 2019

DOI 10.15588/1607-3274-2019-3-15
10. Lobanov A. A. Digital Simulation in the Geosciences / A. A. Lobanov // European Researcher. - 2014. - Vol. 82, № 9 (1). - P. 1611-1619. DOI: 10.13187/er.2014.82.1611

11. Многопараметрический поиск оптимальных маршрутов движения подвижных объектов в условиях дестабилизирующих факторов / [Н. А. Карманова, С. А. Якушенко, Д. А. Маняшин, А. К. Малышев] // Информация и космос. - 2016. - № 4. - С. 144-151. Режим доступа : http://openbooks.ifmo.ru/ru/article/16339/ mnogoparametricheskiy_poisk_optimalnyh_marshrutov__ dvizheniya_podvizhnyh_obektov_v_usloviyah_destabiliziruyuschih faktorov.html

12. Lévy B. Notions of optimal transport theory and how to implement them on a computer / B. Lévy, E. Schwindt // Computers \& Graphics. - 2018. - Vol. 72. - P. 135-148. DOI: $10.1016 /$ j.cag.2018.01.009

13. Securing display path for security-sensitive applications on mobile devices / [J. Cui, Y. Zhang, Z. Cai et al.] // Computers Materials and Continua. - 2018. - Vol. 55, № 1. P. 17-35. DOI: https://doi.org/10.3970/cmc.2018. 055.017

14. Творошенко I. C. Розробка просторової моделі геоінформаційної підтримки людей 3 обмеженими можливостями, що пересуваються на інвалідних колясках, у місті Харкові / I. С. Творошенко, В. А. Табашник // Збірник наукових праць ХНУПС. 2018. - Вип. 1 (55). - С. 122-128. DOI: 10.30748/zhups. 2018.55.17

15. GIS for Fire Station Locations and Response Protocol Esri [Electronic resource]. - Access mode : https://www.esri. com/library/whitepapers/pdfs/gis-for-fire.pdf

16. Hesse G. Conceptual Survey on Data Stream Processing Systems / G. Hesse, M. Lorenz // Parallel and Distributed Systems : 21st International Conference IEEE (ICPADS), Melbourne, 14-17 Dec. 2015 : proceedings. - Melbourne : IEEE, 2015. - P. 797-802. DOI: 10.1109/ICPADS.2015. 106

17. Schmitzer B. A sparse multiscale algorithm for dense optimal transport / B. Schmitzer // Journal of Mathematical Im- 
aging and Vision. - 2016. - Vol. 56(2). - P. 238-259. DOI: 10.1007/s10851-016-0653-9

18. Мордухов М. А. Использование инструментов транспортного моделирования для прогнозирования изменений дорожно-транспортной ситуации при реконструкции улично-дорожной сети / М. А. Мордухов, М. А. Самсонов // Организация и безопасность дорожного движения : X Международная научно-практическая конференция, посвященная 85-летию со дня рождения д.т.н., профессора Л. Г. Резника : в 2 томах, Тюмень, 16 марта 2017 г. : тезисы докладов. - Тюмень : Тюменский индустриальный университет, 2017. - С. 425-429.

19. Ratajczyk B. The role and place of volunteer fire service in the national rescue and firefighting system / B. Ratajczyk // Bezpieczeństwo i Technika Pożarnicza. - 2016. - Vol. 43, Issue 3. - P. 3-20. DOI: 10.12845/bitp.43.3.2016.1

20. The state of knowledge of qualified first aid among firefighters of the national and volunteer fire service / [Wójcik Grzegorz, Surowicz Dawid, Kuźnicki Mateusz, Myślak Marek] // Bezpieczeństwo i Technika Pożarnicza. - 2017. Vol. 45, Issue 1. - P. 102-110. DOI: $10.12845 /$ bitp.45.1.2017.8

21. Most reliable path-finding algorithm for maximizing ontime arrival probability / B. Y. Chen, C. Shi, J. Zhang et al. // Transportmetrica B: Transport Dynamics. 2017. - Vol. 5, № 3. - P. 253-269. DOI: 10.1080/21680566. 2016.1169953

22. Andrew V. Goldberg Point-to-Point Shortest Path Algorithms with Preprocessing / Andrew V. Goldberg // Theory and Practice of Computer Science : 33rd Conference on Current Trends in Theory and Practice of Computer Science, Harrachov, Czech Republic, 20-26 January 2007 : proceedings. - Harrachov : SOFSEM, 2007. - P. 88-102. DOI: 10.1007/978-3-540-69507-3 6

23. Sun Y. Discovering time-dependent shortest path on traffic graph for drivers towards green driving / Y. Sun, X. Yu, R. Bie et al. // Journal of Network and Computer Applications. - 2017. - Vol. 83. - P. 204-212. DOI: 10.1016/j.jnca. 2015.10.018

24. The Global Optimal Algorithm of Reliable Path Finding Problem Based on Backtracking Method / [Liang Shen, Hu
Shao, Long Zhang et al.] // Mathematical Problems in Engineering. - 2017. - Vol. 2017. - P. 1-10. DOI: $10.1155 / 2017 / 4586471$

25. Imzaem Abdulkareem Multi-criteria decision making to select the best monorail route / Imzaem Abdulkareem, Ammar A. Shubber, Asseel Sabah // Global Journal of Engineering Science and Research Management. - 2018. P. 16-32. DOI: 10.5281 /zenodo. 1255758

26. Творошенко I. C. Особливості застосування геоінформаційний технологій під час розробки мережі просторових об'єктів оперативного пожежогасіння в місті Харкові / І. С. Творошенко, О. О. Крамаренко // Геоінформаційні технології у територіальному управлінні та експертних дослідженнях: правові, організаційні, технічні проблеми : IV Міжнародна науково-практична конференція, Львів, 4-6 жовтня 2017 р.: тези доповідей. - Львів : Львівська політехніка, 2017. - C. 159-163.

27. Творошенко I. С. Удосконалення просторової мережі навчальних закладів міста Сєвєродонецька на основі геоінформаційного аналізу / I. С. Творошенко, А. Р. Шевченко // Системи обробки інформації. - 2018. Вип. 1 (152). - С. 46-52. DOI: 10.30748/soi.2018.152.07

28. Творошенко I. С. Практичні аспекти створення вихідної інформації для проведення геоінформаційного аналізу у сфері управління нерухомістю / I. С. Творошенко, В. Р. Мгеброва, В. В. Білий // Збірник наукових праць ХУПС. - 2016. - Вип. 1 (46). - С. 107-111. Режим доступу: http://nbuv.gov.ua/UJRN/ZKhUPS_2016_1_26

29. Творошенко И. С. Анализ процессов принятия решений в интеллектуальных системах / И. С. Творошенко // Системы обработки информации. - 2010. - Вып. 2 (83). - С. 248-253. Режим доступа : http://nbuv.gov.ua/UJRN/ soi 2010_2 56

30. Методи, моделі та інформаційні технології оцінювання станів складних об'єктів : монографія / [С. І. Кучеренко, В. Є. Кучеренко, I. С. Глушенкова, I. С. Творошенко]. Харків : ХНАМГ ; ХНУРЕ, 2012. - 278 с. Режим доступу : http://eprints.kname.edu.ua/29457/ 